\title{
Duše předmětu a tělo modlitby aneb zkoumání sociologických nejistot na prípadu Sóka Gakkai International'
}

\author{
The Spirit of an Object and the Body of a Prayer: Examining \\ Sociological Uncertainties over the Case of Soka Gakkai \\ International
}

Petra Tlčimuková

\begin{abstract}
This case study presents the results of long-term original ethnographic research on the international Buddhist organization Soka Gakkai International (SGI). It focuses on the relationship between the material and immaterial and deals with the question of how to study them in the sociology of religion. The analysis builds upon the critique of the modernist paradigm and related research of religion in the social sciences as presented by Harman, Law and Latour. The methodology draws on the approach of Actor-Network Theory as presented by Bruno Latour, and pursues object-oriented ethnography, for the sake of which the concept of iconoclash is borrowed. This approach is applied to the research which focused on the key counterparts in the Buddhist praxis of SGI - the phrase daimoku and the scroll called Gohonzon. The analysis deals mainly with the sources of sociological uncertainties related to the agency of the scroll. It looks at the processes concerning the establishing and dissolving of connections among involved elements, it opens up the black-boxes and proposes answers to the question of new conceptions of the physical as seen through Gohonzon.
\end{abstract}

KEYWORDS Actor-Network Theory, daimoku, Gohonzon, iconoclash, sociology of religion, Soka Gakkai International

\section{Setkání se Sóka Gakkai International}

Sóka Gakkai International (SGI), globální buddhismus původem z Japonska a zároveň jedno z nejznámějších nových náboženských hnutí, získala pozornost badatelů především díky společensky ožehavým tématům s ní spojených - počínaje technikami konverze (Snow 1993; Dobbeleare 2001) přes kult osobnosti prezidenta Daisaku Ikedy (Chilson 2014) až po politické aktivity (web SGI, Activities for Peace 2015) a pochybné zdroje financování (Kisala

Sociální studia / Social Studies 2/2020. S. 53-69. ISSN 1214-813X.

1 Studie byla podpořena z projektu „Česká společnost, náboženství a př́roda“ (2018-2020) pod Filozofickou fakultou Univerzity Hradec Králové. Poděkování patří nejen všem respondentům, ale také kolegům, kteří mě v práci podporovali, především Tomáši Kobesovi, Anně Kvíčalové a Martinu Švantnerovi a v neposlední řadě konstruktivním kritikám recenzentů. 
2004a: 149, Anonymous 2014). Tento text se ovšem zabývá oblastí náboženské praxe této organizace. Ústřední praktikou Ničirenových buddhistů je pravidelná recitace fráze Nam mjóhó renge kjó. Prostřednictvím ní se členové oddávají učení Lotosové sútry. Dvakrát denně ji odříkávají a čelem při tom směřjí ke Gohonzonu - kopii svitku sepsaného ve 13. století Ničirenem Daišóninem. Ten považoval Lotosovou sútru za nejzásadnější buddhistický text, jehož hlavním poselstvím je, že každý může dosáhnout probuzení v tomto životě. Pro členy SGI představuje Gohonzon předmět nejvyšší úcty a nástroj duchovního cvičení (rocham2010 2014). Svitek nese poselství vepsané čínskými a sanskrtskými znaky s frází Nam mjóhó renge kjó uprostřed. Má mít moc aktivovat buddhovský potenciál v každém jedinci.

Fráze a svitek fungují ve vzájemném partnerství; zdá se, jako by konstituovaly základní nemateriální a materiální složky Ničirenova buddhismu přítomné v každodenní rituální praxi. Cílem studie je prozkoumat jejich vztah, k čemuž využívá teorii aktér-sítí (ANT) umožňující sledovat procesy materializace těchto prvků. Klade si otázku, $\mathrm{k}$ čemu během náboženské praxe dochází, jaká je funkce a místo fráze a svitku. Využití konceptu ikonoklaše umožní vidět, jakým způsobem se střetávají různé historické i současné podoby Gohonzonu, a popsat situace, v nichž jedinci, instituce, texty či svitky pomohly nové podoby definovat. Text ukazuje, jak Gohonzon zrcadlí a proměňuje vnitřní stav člověka, a také to, že je pojítkem formujícím komunitu. Docházím k závěru, že svitek i recitující člen jsou ztělesněním fráze, a tedy zpř́tomněním Mystického zákona, správného řádu světa, a že posloupnost ikonoklašů vedla k současnému zdůrazňování př́tomnosti Gohonzonu v člověku. Studie je další v řadě českých ANT studií zabývajících se náboženstvím (Konopásek 2010; Paleček 2010; Konopásek a Paleček 2006, 2011, 2012; Fujda 2013, 2015, 2016; Kobes 2018; Spalová 2012; Kvíčalová 2019), která se ovšem tentokráte zaměřuje na buddhistickou rituální praxi.

\section{Vztah materiální a nemateriální složky náboženství jako výzkumný problém}

Původ rozlišování mezi materiálním a nemateriálním bývá v evropském kulturním kontextu spojován s křest’anstvím a mýtem o vyhnání z ráje; oddělení člověka od Boha, věčnosti a duchovní sféry a zanechání $\mathrm{v}$ jeho pomíjivé tělesnosti a utrpení je $\mathrm{v}$ křest’anské perspektivě trestem za prvotní hř́ích. Došlo k oddělení materiálního světa od Boha, k němuž se má duše člověka po smrti navrátit. Ztělesňování Boha v průběhu lidských dějin má nicméně v pohledu křest’anské teologie zásadní význam. Jak život Ježíše Krista, tak i různá boží zjevení mají dokládat, že Bůh stále s člověkem prostřednictvím tohoto světa přichází do styku. Jak poznamenávají Espirito Santo a Tassi v knize Making Spirits: Materiality and Transcendence in Contemporary Religions, prakticky ,[j]akýkoliv duchovní kontakt s Bohem vyžadoval materiální instanci“ (2013: 1). Ačkoliv tedy mělo dojít k oddělení materiálního a duchovního, přičemž materiálnímu se dostalo podstatně nižšího statusu, vzájemná komunikace obou sfér zajišt'ovala fungování a určovala hodnoty tohoto světa. A to, že v těle člověka sídlí nesmrtelná duše, má být důkazem, že se od něj Bůh zcela neodvrátil.

$\mathrm{S}$ nástupem modernity $\mathrm{v}$ průběhu 18 . a 19 . století mělo dojít $\mathrm{k}$ obratu $\mathrm{v}$ př́stupu k duchovnímu světu, který v evropském kontextu po staletí reprezentovala římskokatolická církev. Tento obrat, který Max Weber sociologicky popsal jako „odkouzlení světa“ (1998, 
s. 127-128), měl spočívat v postupném prosazování racionálního vysvětlování světa a vytlačení magického myšlení a náboženství ze života lidí, jeho sekularizování. Komplexní proces „očišt’ování“ (srov. např. Latour 1993, s. 10; Espirito Santo a Tassi 2013, s. 2) světské sféry od náboženské, materiálního od duchovního, měl vyústit $\mathrm{v}$ nezávislý přirozený svět, kde objektivita a humanistické morální hodnoty již nebudou ovlivňovány světem duchovním, jehož těžiště je mimo tento svět. Cílem mělo být zpřetrhání vazeb tak, aby se tento svět stal vůči světu nemateriálnímu absolutně imunním (srov. Espirito Santo a Tassi 2013, s. 2-4). V procesu oddělování domén moderních společností mělo dojít k oddělení materiálního od duchovního a materiální bylo nadále považováno za duchem opuštěné (srov. Espirito Santo a Tassi 2013) a neschopné vládnout nad formálními institucemi (Fenn 2001). Náboženství bylo $\mathrm{v}$ procesu modernizace nejen vyděleno, a spolu s tím také zbaveno právní i správní moci; jako specifická doména také podlehlo vnitřní pluralizaci, čímž se dále zeslaboval jeho vliv na společnost, měnilo se jeho místo i role (Fenn 2001, s. 11). Stalo se doménou odporující modernitě (srov. Kobes 2018).

Sociologie rodící se v tomto období funkční diferenciaci jednotlivých oblastí a nekompatibilitu náboženství a modernity předpokládá. John Law (1994) i Bruno Latour (1993) kritizují představu moderní společnosti utvářející se v procesu očištování. Duální světy vzniklé v procesu očišt'ování lidského od přírodního, vnitřního od vnějšího, materiálního od nemateriálního, subjektivní zkušenosti od objektivního poznání nedovolují badatelům poznat komplexní povahu světa. Náboženství se stalo nesouměřitelné se světem vědecké racionality; náboženství bylo odděleno od vědy, víra od vědění a ontologie od epistemologie (Latour 2010, s. 40). Př́ístup společenských věd k náboženství je nadále určen zájmem o lidskou společnost a funkce, které v ní náboženství plní, dodržováním principu redukcionismu a s tím souvisejícím odmítáním věnovat pozornost otázkám ontologie posvátna, Boha a bohů. Prvotní akademické snahy určit podstatu náboženství prostřednictvím posvátného a transcendentního vystřídal společenskovědní př́istup definující náboženství jakožto odpověd' na lidské potřeby (srov. Segal 1985, s. 78-79). Otázky týkající se náboženských pravd, povahy posvátna atd. jsou ponechány teologům a filozofům náboženství. Náboženství je vysvětlováno pomocí trhu, psýché či společenské funkce. Předpoklad od materiálna očištěného náboženství nutí sociální vědce soustředit se na dimenzi víry a její kontinuity. Úskalí, na které naráží modernistická sociologie a výzkum náboženství, výstižně shrnuli Espirito Santo a Tassi (2013: 2):

To „reálné“ se skládá do tvarů - od hmotných socio-ekonomických a politických podmínek, patologií a potlačených psýché po zděděné evoluční dispozice manifestované skrze kognitivní mechanismy. Hmota (včetně těla) zůstala jakousi „maskou“, která zakrývá nebo obléká jiné zásadnější znaky naší existence jakožto materiálních bytostí. Ve společenských vědách náboženství bylo a stále je o „něčem“ jiném, a tudíž v něj je potřeba ,věřit“.

Toho, že jevy, kterými začalo být náboženství v moderních společnostech vysvětlováno, nabyly stejného statusu, kterého dříve užívalo náboženství, si všiml John Law i Bruno Latour. Ontologie Boha či posvátna byla nahrazena ontologií společnosti, př́rody, trhu apod., jejichž povaha je taktéž nadindividuální a jejichž ontologie také zůstává nevyjasněná (srov. Kobes 2018). Nejenže náboženství ve společenských vědách ztratilo ontologický status, ale ani 
u toho, co je má zprostředkovávat - lidé, obrazy, texty -, se nepředpokládá, že ve skutečnosti nese posvátnou kvalitu. Tito prostředníci jsou chápáni jako fetiše, ,projekce víry na němý pasivní předmět“ (Bell 2010). Zatímco nepochopení fungování světa stojí dle modernistů za tím, že si lidé ve své naivní víře vytvářejí prostředníky - fetiše -, sami modernisté jsou přesvědčení, že jsou schopni nazírat skutečnost - fakta - bez prostředníků. Podle nich se vlastně jedná o nesprávné nazírání kauzality dějů, chybnou teorii aktérství (Latour 2010: 8):

Fetišista je obviněn z pomýlení týkajícího se původu moci. Postavil modlu svýma vlastníma rukama - svou vlastní prací, svou vlastní lidskou fantazií, svým vlastním lidským úsilím -, a přesto nyní připisuje tuto práci, fantazii a úsilí předmětu, který stvořil.

Podle Latoura řeší sociologové v očištěných světech původu aktérství empirii neodpovídajícím způsobem; aktérství je připsáno člověku a předmět se stal pasivní součástí př́rody. Náboženský předmět vystupuje jako fetiš, nečinná hmota klamně vystupující jako vtělení posvátného. Jaký přístup, který by dovoloval lépe uchopit realitu, nabízí teorie aktér-sítí (ANT)?

Namísto práce spojené s „očišt’ováním“ se ANT zaměřuje na komplexní procesy ustavování skutečnosti. „Problém sociálního řádu je nahrazen zájmem o plurální procesy socio-technického uspořádávání“ (Law 1994: 3). Náboženství se v takovém přístupu již neukazuje jako oddělená oblast zbavená moci s arzenálem falešných model, ale je možné ji sledovat jako procesy shlukování a odlučování hmotných a nehmotných prvků. Zájem badatelů se pak může soustředit nejen na to, jaké heterogenní prvky náboženství tvoří, ale také na způsoby ustavování toho, co je pojímáno jako náboženství, proměny jeho hranic a podobně. Namísto vědeckého ikonoklasmu praktikovaného na náboženství nabádá Latour pojmout výzkum jako proces zaměřený na tzv. ikonoklaš, tedy střetávání obrazů, ve kterém jeden obraz nahrazuje druhý. Tento střet je dle Latoura doprovázen nejistotou vztahující se k roli lidské práce v produkci (2001, s. 18), autorství jednání. Tato nejistota nutí věnovat pozornost nejen lidským, ale také mimolidským aktérům a mapovat pohyb obrazů se zaměřením na prvky aktivně přenášející významy (srov. Latour 2001, s. 21). Z fabrikování skutečnosti nelze vyloučit zásahy mimolidských činitelů. Symetrický prŕstup proponovaný Lawem i Latourem umožnuje zkoumat aktéry jako nestabilní hybridy uspořádávané do různých sítí prostřednictvím řeči, jednání, způsobů ztělesňování a reprezentování (srov. Law 1994, s. 23). Sám aktér-člověk je nahlížen jako komplexní a dynamický shluk vazeb, jako „sít’ různých materiálü“ (Law 1994: 24).

K dynamice materiálna přesouvá zájem také Graham Harman v knize Immaterialism: Object and Social Theory (2016). Také Harman upozorňuje, že dobrá sociologická teorie a priori vylučuje jakékoliv druhy bytostí z analýz (2016, s. 4). Problém materiálního předmětu byl dle Harmana $\mathrm{z}$ pozic společenských věd doposud nazírán v zásadě dvěma způsoby: 1) se zájmem o to, z čeho je tvořen, 2) co dělá. První způsob přináleží tradičnímu materialismu, druhý především ANT. Zkoumání předmětu pomocí ANT dovoluje vidět proces ustavování předmětu z mnoha prvků a práci prostředníků, kteří tyto prvky dislokují, tj. přenášejí a modifikují napříč časovými a prostorovými rámci, a stabilizují jejich sémiotické, materiální o nemateriální podoby. Výzkum reality prostřednictvím střetávání podob předmětu ukazuje předmět jako dynamickou sít' vazeb, jako výsledek jednání, které by „mělo být vnímáno jako 
uzel, chomáč a konglomerát mnoha překvapivých množin činitelů, kteří musí být pomalu rozpleteni“" (Latour 2005: 44).

Náboženství nadále nevystupuje jako separovaná doména duchovna, jejíž fungování je v zájmu zachování puncu vědeckosti vysvětlitelné pouze prostřednictvím jiné oblasti. „Náboženství nemusí ,být vysvětlováno“ sociálními silami, protože je obsaženo v jeho vlastní definici - skutečně v jeho vlastním názvu - že spojuje entity, které nejsou součástí sociálního řádu“ (Latour 2005: 7). Ontologie těchto entit není a priori zpochybňována - je naopak úkolem badatelů ji zprostředkovat a ukázat, jak je jejich jednání distribuováno. V tomto ohledu ANT prakticky navazuje na Thomasův teorém, který předpokládá, že pokud aktéŕi definují situaci jako reálnou, je reálná ve svých důsledcích (1958). Pokud tedy ti, které sociální vědci zkoumají, věří v existenci náboženských světů a entit, lze sledovat, jak ovlivňují tyto světy a entity jejich jednání.

Proč neříct, že to, co se počítá v náboženství, jsou ty bytosti, které nutí lidi jednat přesně tak, jak každý věřící vždy tvrdil. Bylo by to empiričtější a zřejmě i vědečtější, uctivější a mnohem ekonomičtější než vynález dvou nemožných neexistujících míst: mysli věřícího a sociální reality, které jsou schované za iluzemi podepřenými ještě většími iluzemi. (Latour 2005: 235)

Společenské vědy zkoumají vztah náboženství a společnosti, jako by se jednalo o dvě autonomní entity i v př́ípadě SGI. Taková konceptualizace vychází z předpokladu funkční diferenciace společností. $\mathrm{V}$ př́padě SGI je takový výzkum zaměřen na adaptační strategie $\mathrm{v}$ jednotlivých národních státech (je tedy navíc okleštěn metodologickým nacionalismem), způsoby rekrutování nových členů a angažovanost ve veřejné sféře. Můj výzkum ovšem zaměřuje svou pozornost na sociální procesy ustavování náboženského objektu. Přesvědčení, že svět duchovní působí na svět fyzický a že je možné oba tyto světy prostřednictvím správného vykonávání rituálů ovlivňovat, ustavuje základní princip, o který se opírá náboženská praxe; náboženské předměty jako Gohonzon v těchto rituálních praktikách zaujímají důležité místo. Jelikož v ANT je předmět pojímán jako výsledek jednání mnoha aktérů, zaměřím se právě na způsoby existence předmětu. Usiluji o zodpovězení otázky, jak je ustavován ústřední předmět úcty zvaný Gohonzon, v jakém vztahu je k těmto procesům fráze Nam mjóhó renge kjó, potažmo kdy dochází k rekonfiguraci prvků shlukujících se v Gohonzon v kontextu praktik SGI. Metodologickou oporou se mi v mém úsilí stala kniha Reassembling the Social, ve které Latour nabádá ke zkoumání pěti zdrojů sociologických nejistot: povahy skupiny, povahy jednání, povahy objektů a povahy faktů a povahy sociálních věd (2005: 21-121). Především s využitím etnografických metod je možné při výzkumu těchto sociologických nejistot zkoumat ad 1/ kontradiktorní způsoby, kterými aktér získává identitu, tedy způsoby získávání kolektivní identity a vymezování se vůči jiným skupinám, ad $2 /$ průběh jednání různorodých aktérů, kteří situačně mění původní vlastní či skupinové cíle, ad 3/ typy aktérů, kteří se účastní vyjednávání v jejich heterogenitě, ad 4/ vztah prrírodních věd ke zbytku společnosti a ad 5/ povahu empirických poznatků a místo společenských věd (srov. Latour 2005, s. 22). $\mathrm{V}$ takto orientovaném výzkumu mohou badatelé zodpovědět otázky zabývající se tím, z čeho je tvořeno sociálno, co jedná, když jednáme my, k jakému uskupení náležíme, co chceme a jaký svět chceme sdílet (Latour 2005, s. 138). Teorie jednání v podání ANT předpokládá, že do jednání jednoho člověka je vždy zapojeno mnoho dalších heterogenních aktérů, a práce 
sociologa spočívá ve výzkumu jejich konkrétních tělesných podob, které nejsou pouze antropomorfní (Latour 2005, s. 53-54). K popisu těchto forem tělesnosti Latour uživá technický termín figurace a dodává, že „,[v]elká obtíž ANT spočívá v tom, že bychom se neměli nechat zastrašit typem figurace: ideo-, techno- nebo biomorfismy jsou morfismem stejně tak, jako inkarnací nějakého aktanta v jednoho aktéra“ (Latour 2005: 54). V tomto smyslu tedy sleduji figurace Gohonzonu a jejich proměny.

Počátek terénního výzkumu spadá do jarní Vídně roku 2010, kdy jsem poprvé navštívila Kulturní centrum rakouské Sóka Gakkai International (Ö-SGI). Po tř́měsíčním pobytu následoval dlouhodobý etnografický výzkum v SGI-Česká republika (SGI-ČR) a v roce 2019 opět intenzivní trríměsíční výzkum v Ö-SGI. V průběhu posledních let jsem se formou (často zúčastněného) pozorování nepravidelně podílela na týdenních i měsíčních setkáních a výročních oslavách. V průběhu výzkumu jsem se členy SGI-ČR vedla deset formálních narativních rozhovorů, pět polostrukturovaných rozhovorů se členy Ö-SGI a mnoho rozhovorů neformálního charakteru. Důležitou součástí výzkumu bylo také studium primárních materiálů doporučovaných členy.

Během let 2013 až 2016 jsem při pracovních výjezdech vykonaných nejčastěji v rámci plnění projektu CHINET (CZ.1.07/2.3.00/20.0152) po Evropě, Spojených státech amerických a Asii měla možnost navštívit a prozkoumat několik center SGI: navštívila jsem ústředí SGI v Tokiu, New York City, Washingtonu D. C. nebo Chicagu. Při těchto návštěvách, ale také při jiných př́ležitostech mimo prostředí oficiálních center SGI jsem hovořila s desítkami členů organizace po světě a naslouchala jejich př́běhům a názorům, praktikovala jsem s nimi před Gohonzonem. Ačkoliv můj výzkum probíhal primárně v české a rakouské větvi SGI, poznatky ze zahraničních návštěv a rozhovorů se staly jeho neodmyslitelnou součástí.

\section{Mikrovhled do SGI: čantování daimokou před Gohonzonem}

Když ve 30. letech 20. století Cunesaburó Makiguči zakládal organizaci Soka Kjoiku Gakkai byl členem Ničiren šóśú, významné školy japonského buddhismu. V průběhu 60 . let laická buddhistická Sóka Gakkai pod vedením třetího prezidenta Daisaku Ikedy začala rozvíjet své mezinárodní ambice. Přerod v nadnárodní organizaci s posláním realizovat tzv. „Lidskou revoluci“ (jap. Ningen kakumei) byl stvrzen roku 1975 vznikem Sóka Gakkai International (SGI). Dnes dle údajů SGI organizace vykazuje kolem 12 milionů př́znivců ve 192 zemích světa. Recitace Nam mjóhó renge kjó před Gohonzonem má v procesu celosvětové proměny zásadní roli.

Generální mítink SGI konaný v Praze roku 2014 oslavoval se svými téměř sty členy 50 let kósen rufu, tedy šiření Ničirenova buddhismu, v Česku. První skupina věnující se Ničirenovu buddhismu zde vznikla v 80. letech, ale už v roce 1964 prezident Daisaku Ikeda poprvé navštívil Československo. V české brožurce Základy Budhismu Ničirena Daišónina (n.d. a) se píše o kósen rufu následovně: „Spisovně kósen-rufu znamená ,zeširoka objasnit a rozš́irit (budhismus) ${ }^{c}$. Prakticky to znamená učit ostatní, jak se modlit Nam-mjóhó-rengekjó, nebo vysvětlovat jiným budhistický pohled na život“" (n.d.). Úkol šírit Ničirenův buddhismus mají členové plnit tak, že budou vyučovat rituální praktiku a koncepci světa. Kósen rufu uskutečňované šiřrením praxe recitování, počeštěle „,̌antování“, před svitkem má směřovat k tzv. „Lidské revoluci“. 
Členové SGI praktikují buddhismus, který kázal ve třináctém století japonský mnich Ničiren. Středem Ničirenova buddhismu je fráze Nam-mjóhó-renge-kjó a mandala, označovaná jako Gohonzon. Existují tři základní elementy Ničirenova buddhismu: čantovat frázi Nam-mjóhórenge-kjó jako frázi modlitby pro sebe a pro ostatní, studium Ničirenových učení a snažit se podělit o učení buddhismu, šíriit buddhistickou perspektivu životu vrozené důstojnosti a ponciálu (sic!). Členové SGI provádějí ranní a večerní praktikování, známé jako Gongjó, které se skládá z čantování Nam-mjóhó-renge-kjó a z recitace části Lotosové sútry. (,Základní praktikování“ 2014)

Takto informuje oficiální webová stránka Sóka Gakkai International-Česká republika založená členy roku 2012 v sekci „Praktikování buddhismu“ a její podkapitole „Základní praktikování“. Podle vyjádření v první větě určuje členství v SGI právě praktikování. Následující věta umist'uje frázi Nam mjóhó renge kjó a Gohonzon do středu Ničirenova buddhismu. Čantování před svitkem propojuje členy a způsobuje proměnu.

\section{Daimoku: ztělesňování slova}

Fráze Nam mjóhó renge kjó označovaná daimoku odkazuje k názvu Lotosové sútry a aktu odevzdání se jejímu poselství. Brožurka Buddhismus Ničirena Daišónina: Filozofie vítězného života (2008) překládá frázi jako „Vzývám sútru lotosového květu skvostného zákona“. Na webových stránkách SGI-ČR (Nam-Mjóhó-Renge-Kjó, 2014) se dozvídáme o jednotlivých prvcích daimoku, kde: Nam vystupuje jako prostředek oddání se Zákonu života; Mjóhó je Mystickým Zákonem s nehmotnou esencí, která má smysly uchopitelné proměnlivé ztělesněné projevy; Renge je květ lotosu odkazující k vzájemnosti př́činy a následku, tedy vzniku karmy; Kjó znamená sútru, hlas učení Buddhy. Odpovědnost za kvalitu života člověka nese jedinec, závisí na jeho myšlenkách, slovech a činech. Brožura představuje Nam mjóhó renge kjó jako zprostředkovatele změny směrem $\mathrm{k}$ buddhovství. Daimoku obíhá v rámci vztahů ustavených mezi jedincem a dalšími prvky a určuje kvalitu spojení, analogicky k elektřině procházející kabely a spojující spotřebiče se zdrojem. Doslova ustavuje kvalitu karmy jedince a odkazuje na možné způsoby existence. Také web SGI-ČR představuje čantování daimoku jako způsob realizování buddhovství: „Jako př́mý a bezprostřední prostředek $\mathrm{k}$ jeho dosažení a radosti z něj představil [Ničiren] praxi čantování ,Nam-mjóhó-renge-kjó““ („Lidská revoluce“ 2014). Slabika kjó je hlasem samotného Buddhy, její vyslovení je aktem zhmotňujícím Buddhovo učení. Tělo čantujícího člena se při vyslovení slabiky stává reprezentací kdysi žijícího těla Buddhy. Vyslovením slabiky kjó čantující otvírá cestu Mystickému zákonu.

$\mathrm{Na}$ těchto procesech se nepodílí pouze čantující člen. Pro ANT je charakteristické, že redefinuje koncepci aktérství tím, že odkazuje k multiplicitě aktérů, kteř́ jsou zapojeni, když jedinec koná (Latour 2005, s. 44). Rozbor textu ukazuje figurace daimoku i to, že nejen praktikující jedná s cílem zajistit proměnu. Do čantování je zapojena řada prvků např́íc časem i prostorem, na něž se člen při artikulování jednotlivých slabik daimoku repetitivně napojuje.

Texty SGI pracují s dichotomií tělo a mysl, hmota a vědomí. Brožura Základy Budhismu Ničirena Daišónina (n.d. a) pojímá tělo a mysl jako dva odlišné, ale neoddělitelné aspekty bytí, kde tělo představuje „fyzický život“ a mysl „život duševní“. Oba tyto aspekty života jsou kauzálně propojené; stav mysli ovlivňuje fyzický stav člověka a práce na něm je tedy zásadní pro fyzický prospěch. Právě $\mathrm{k}$ tomu má dopomoci pravidelné čantování daimoku. 
V textu „How to talk about the body“, který volá po nové konceptualizaci těla, Latour navrhuje pojímat tělo jako „rozhraní, které se stane mnohem lépe popsatelnější, když se naučí být ovlivňováno dalšími a dalšími prvky“ (Latour 2004: 206). Odmítá esencializovat tělo a pojímat ho jako „provizorní obydlí něčeho vyššího“. Důležité je sledovat cesty, které za sebou tělo nechává, když se učí poznávat svět.

Př́iběhy čantujících mají být důkazem toho, že praxe funguje, proměňuje fyzický i psychický stav těch, kteří čantují, i jejich okolí. Část každého mítinku SGI je vyhrazena pro sdílení osobních zkušeností. Tyto př́iběhy mají svůj prostor jak v internetové prezentaci SGI (např. „People \& Perspectives“ n.d.), tak ve sbírkách, které členové mají možnost studovat. Často zpravují o tom, jak do života člena přišla nemoc, kterou s pomocí daimoku překonali.

Vincent se se svou ženou Michelle do České republiky přestěhoval před mnoha lety. Sdílel svůj příběh ve sbírce (n.d. b) spolu s dalšími členy různých národností, kteří se ve většině případů alespoň na nějakou dobu stali součástí SGI-ČR. Hlavní zápletkou Vincentova př́běhu byla jeho náhlá srdeční prríhoda, kterou ovlivnil zapojením daimoku:

Při bolestivých chvílích, kdy není jasno, jak dlouho bude bolest trvat, ani jestli budete schopni ji překonat, a když se cítíte na prahu smrti a tušíte, že není ještě pravý čas, recitoval jsem vnitřně a hluboce Ničirenovo Nam-Mjó-Hó-Renge-Kjó. Oddával jsem se celým srdcem - Nam - v jeho významu: spojit se s tím zázračným či mystickým Zákonem života a smrti, tj. Mjó-Hó-Renge-Kjó. Byl jsem přesvědčen, že nemám panikařit a ztrácet svůj klid, že mám dýchat pravidelně a soustředěné recitování mi v tom velice pomáhalo, jakoby všechna ta buddhistická léta se shromáždila a přinesla důvěru a klid k závěru. Navíc jsem dobře věděl, že při svých potížích nejsem sám, že rodina a mnozí přátelé se mnou také recitují Nam-Mjó-Hó-Renge-Kjó, nebot' úspěch jednoho je úspěchem každého $z$ nás. (n.d.)

Bolest je ve Vincentově vyprávění aktérem: vystupuje jako parazit, který fatálně ochromuje. Způsob, jakým překonat bolest, bylo zvnitřnit v sobě daimoku. Ztělesnění daimoku nespočívalo pouze v prosté recitaci, tedy práci bránice, hlasivek atp. Daimoku bylo v nejtěžších chvílích ve Vicentově srdci. O čantování srdcem mluvili mnozí další členové. Spojení jedince a daimoku probíhá v srdci, a pokud se tak děje, už zde nefiguruje žádný prostředník, jde o intimní spojení v jedno, o reprezentaci Mystického zákona v těle člověka. Daimoku ve Vicentově těle pomohlo zachovat klid a pravidelný dech, tedy základní tělesnou funkci v situaci, kdy jiná základní tělesná funkce vypadla. Prvek zázraku, který Vincent zmiňuje, je ve výpovědích obvyklý. Náhlé uzdravení smrtelně nemocného člověka jako výsledek čantování utvrzuje ostatní v tom, že daimoku je zázračný nástroj, který Ničiren dal lidem.

$\mathrm{V}$ př́bězích lze sledovat specifické pojetí kauzality, kterým členové dokládají fungování daimoku. Keiko ve sbírce píše o své mamince, která se se smrtelnou diagnózou dostala do nemocnice:

Každý den odhodlaně čantovala na nemocniční posteli a výsledek byl takový, že ji po nějaké době bez operace v dobrém zdravotním stavu propustili z nemocnice. Věc se měla tak, že maminka byla označena za pacientku trpící nevyléčitelnou nemocí. Po vyřízení potřebných postupů bylo rozhodnuto, že její operace bude hrazena státem. Maminka už na operaci pouze čekala. Nakonec se ale ukázalo, že diagnóza byla chybná. Vlastní zkušenost maminku přesvědčila, že tento buddhismus funguje a hned po propuštění z nemocnice jsem i já se svými dvěma sestrami vstoupila do Sóka Gakkai. (n.d.) 
Čantování př́mo vedlo k propuštění z nemocnice. Chybná diagnóza je tak stejným zázrakem, jako by bylo uzdravení se; z pohledu Keiko a její matky se jednalo o důkaz, že čantování funguje.

Ničirenův buddhismus učí, že osobnost a jednání jedince tvoří jeho okolí. Charakter vnějšího prostředí má původ uvnitř jedince. Vnitřním prostředím je myšleno tělo i mysl, a vnějším okolí, nejčastěji v podobě rodiny, přátel a společnosti (př. Hochswender et al. 2017, s. 18). Zároveň tyto dvě domény nefungují autonomně. Propojuje je daimoku. Dělení vnitřní domény na tělo a mysl má být jen zdánlivé. Kapitolka nazvaná „Jednota mysli a těla“ v Základech Budhismu Ničirena Daišónina (n.d. a) mluví následovně:

V principu to znamená, že dva zdánlivě odlišné aspekty těla (čili fyzického života) a mysli (duševního života), jsou dvě navzájem související fáze bytí, a jsou proto neoddělitelné. $Z$ toho plyne, že duševní utrpení způsobuje nevyhnutelně utrpení fyzické. (n.d.)

V knize Buddha ve Tvém zrcadle stojí: „Buddhismus zdůrazňuje vnitřní, osobní přeměnu coby způsob, jak zavést trvale udržitelná řešení světových problémů“ (Hochswender et al. 2017: 18). Daimoku je pojítkem mezi čantujícími a okolím, ovšem je také lepidlem, které umožňuje mluvit o SGI jakožto kolektivu. „To je to, co nás odlišuje od ostatních buddhistů, víte. V tomhle buddhismu čantujeme Nam mjóhó renge kjó,“ ‘̌ekl mi Ladislav, který čantuje již několik desetiletí.

Důležitost kolektivního čantování demonstruje př́pad Wiki. Ta musela vzhledem ke svému zdravotnímu stavu praktikování omezit, což prakticky ohrozilo stávající počet členů kolektivu a potenciálně zpochybňovalo její soudržnost s komunitou. Tato lokálně bezprecedentní a z pohledu norem nastavených $\mathrm{v}$ organizaci těžko obhajitelná situace vyústila $\mathrm{v}$ nutnost nalézt řešení, které by stabilizovalo existující skupinu. Několik klíčových členů se rozhodlo pravidelně docházet do Wikiina domova. Ačkoliv nedošlo k odstranění zdroje nejistot týkajícího se soudržnosti skupiny, tedy Wikiině nemoci, členové touto strategií provizorně vyřrešili situaci. $\mathrm{V}$ př́běhu vystupuje daimoku jako aktér zajištující Wiki život; vypuštění čantování by bylo pro Wiki fatální, př́ímo souvisí s její existencí. V př́ipadě eliminace čantování by došlo $\mathrm{k}$ jeho nahrazení prášky, jež by se staly naopak prostředkem ke smrti. Nejedná se tedy ,jen“ o ohrožení členské identity. Tím, že ostatní členové pravidelně s Wiki čantují, přinášejí jí prostřednictvím daimoku život.

Daimoku je ústředním prvkem ustavujícím kolektiv SGI a umožňujícím šiřrení Ničirenova buddhismu. V okamžiku čantování jedinec není jediným aktérem, nýbrž je jedním ze spektra aktérů, od Buddhy či Ničirena Daišónina po Mystický Zákon, do kterého se aktivně zapojuje a s jehož zapojením daimoku počítá. Při čantování dochází doslova ke ztělesnění daimoku $\mathrm{v}$ jedinci a potřeba jeho ztělesňování nutí členy nacházet inovativní strategie soudržnosti. Kromě těla jedince a SGI kolektivu našlo daimoku své zhmotnění také ve formě uctívaného svitku Gohonzon.

\section{Gohonzon a proměny tělesnosti}

Z pohledu ANT mají předměty schopnost stabilizovat vznikající kontroverze týkající se reality a momenty sociálního vyjednávání, které ohrožují stávající vztahy. V tomto smyslu Latour podává radu ,[n]ásledovat aktéry v jejich proplétání se mezi věcmi, které připojili 
ke svým vlastním sociálním schopnostem, aby učinili neustále se proměňující interakce trvalejšími““ (Latour 2005: 69). Mým cílem je oživit cesty Gohonzonu, jako by se jednalo o konvenčního aktéra, a ukázat, jak dochází k proměňování jeho tělesnosti, respektive ikonoklaši, nahrazování jednoho obrazu jiným.

\section{Figurace, reprodukce a príbuzenství Gohonzonu}

Gohonzon je v buddhismu Ničirena objektem úcty. V japonštině „go“ znamená úctyhodný a „honzon“ znamená object (sic!) fundamentálního respektu. Ničiren definoval základní zákon, pronikající životem a vesmírem, jako Nam-mjóhó-renge-kjó a ztělesnil jej ve formě mandaly. V Gohonzonu, svitku popsaném čínskými znaky a znaky v sanskritu (sic!), Ničiren symbolicky popsal životní stav Buddhovství, který všichni lidé mají. („Gohonzon“ 2014)

Gohonzon je překládán jako „předmět úcty“. Jeho původ se váže k postavě Ničirena Daišónina ze 13. století. Ten nadřadil Lotosovou sútru jiným buddhistickým textům. Právě Lotosová sútra měla být zdrojem, na jehož základě vytvořil vokální praxi daimoku i mandalu zvanou Gohonzon. Gohonzon je protějškem fráze, fyzickou inkarnací Mystického zákona, jenž má ř́́dit fungování člověka a světa. Slovy Latoura lze říci, že Gohonzon představuje jinou figuraci daimoku, která je zase jinou figurací Mystického zákona, jejž jedinec nechává proudit, když čantuje. Ústřední místo svitku je vyzdvihnuto také v knize The Human Revolution, kde je popsán jako „úplný základ Ničirenova buddhismu - pravé náboženství a racionální filozofie“" (Ikeda 1972: 152).

Gohonzon vyvolává změny v každodenním životě praktikujícího. Návod na provádění rituálu s daimoku (recitování Nam mjóhó renge kjó) a gongjó (recitování dvou kapitol Lotosové sútry „Hóben“ a „Džurjó“) nalezneme v brožurce Text modlitby Buddhismu Ničirena Daišónina (n.d. c). Gongjó je rozděleno na tři oddíly, z nichž první je tzv. Poděkování Gohonzonu. Text, který má člen v duchu odříkat, zní následovně:

Vyjadřuji nesmírný obdiv a vdě̌nost Dai-Gohonzonu za Tři Velké Tajné Zákony, které byly předány celému světu. Vyjadřuji nesmírnou vděčnost Ničirenu Daišóninovi - pravému Buddhovi v Pozdním dni Zákona. Vyjadřuji hlubokou vděčnost Ničimoku Šóninovi.

První Gohonzon vytvořený Ničirenem Daišóninem je znám jako Dai-Gohonzon, takzvaný Velký Gohonzon. Více se o něm dozvíme v jednom z gošó, textů, jejichž autorem má být Ničiren, s názvem „The Real Aspect of Gohonzon“ (n.d.). Datuje v něm zjevení Gohonzonu do období působení Buddhy Šákjamuniho, který měl žít na přelomu 6. a 5. století př. n. 1 . Ničiren odmítl být považován za autora mandaly. Nechápe Gohonzon jakožto vynález, nicméně se měl stát prvním, kdo mu dal materiální podobu. Díky Ničirenovi mělo dojít k prvnímu překladu Gohonzonu, a to do podoby svitku.

Webová stránka www.sokaspirit.com informuje, že Ničiren sám vytvořil mnoho přepisů Dai-Gohonzonu, jež navzájem nejsou identické (,FAQ“ n.d.). Také vysocí kněží vytvářeli během staletí přepisy, v nichž neměnná zůstala pouze střední část s nápisem Mjóhó renge kjó a Ničirenovým podpisem. Jedním z těch, kteří vytvořili historicky významnou kopii DaiGohonzonu, byl Ničikan Šónin. Jeho kopie získala důležitost po exkomunikaci SGI z Ničiren 
šóšú v roce 1991, následkem čehož zůstal Dai-Gohonzon instalovaný v Taisekidži. Členům SGI byl zamezen prŕstup také $\mathrm{k}$ jeho novým kopiím z rukou stávajících kněží, kteří byli jejich exkluzivními tvůrci. Omezení př́stupu a možnosti obdržet kopie Gohonzonu znamená hrozbu uzavření Světa Buddhy a zároveň odepření autority ke kontrole šíření Mystického zákona. Gohonzony, které SGI zprostředkovává svým členům, jsou typem tzv. okatagi Gohonzonů. Okatagi znamená „dřevořez“, a ačkoliv „vlastní dřevořezy přestaly být vyráběny před desetiletími“ („FAQ“ n.d.), SGI tak označuje reprodukce Ničikanova Gohonzonu vytvořené procesem tisku. Zatímco Ničikanův Gohonzon není zpochybňován, kritice ze strany Ničiren šóšú je vystaven způsob, jakým SGI vyrábí jeho kopie. Na tuto kritiku SGI reaguje prohlášením, že „,[z]působ, jakým je Gohonzon vyráběn, nemá žádný vliv na prospěch, který získáváme z čantování k němu“ („FAQ“ n.d.), a zároveň obviňuje Ničiren šóšú z exkluzivismu. Druhá česky psaná brožurka, sleduje historické kořeny každého Gohonzonu až k původnímu svitku: „[v]šechy Gohonzony mají původ v Dai Gohonzonu, který nakreslil Ničiren Daishónin 12 (sic!) ř́jna 1279 a jinými slovy: všechny Gohonzony jsou přepisem Dai Gohonzonu“.2

Vztah mezi původním Dai-Gohonzonem, Ničikanovým Gohonzonem a reprodukcemi Ničikanova Gohonzonu, které obdrželi členové SGI, je SGI neustále nucena legitimizovat. Jedná se o př́iklady ikonoklaše, kde dochází ke střetávání různých variant svitku, kterým je z pozice SGI a Ničiren šóšu připisována různá autorita a moc. Spor o legitimitu reprodukcí Gohonzonu SGI řeší 1) delegitimizací role Ničiren šóšú jako šiřitele Ničirenova buddhismu a 2) snížením důležitosti způsobu produkce kopií. SGI zmírňuje důležitost př́mé organické linie př́buzenství Gohonzonů a přichází s alternativními strategiemi legitimizace, v nichž se sama se stává exkluzivním šiřitelem pravého Ničirenova buddhismu.

\section{Gohonzon a propojování aktérů, prostorů a časů}

Mezi Gohonzony existuje př́buzenská vazba. Svitky jsou pojítkem ustavujícím komunitu a také aktivizují vazby mezi věcmi, lidmi a místy mnohdy časově i prostorově vzdálenými. Praktikování ustavuje spojnice mezi Buddhou Šákjamunim, Ničirenem a čantujícím, který se Buddhou stává. Gohonzon je chápán jako předmět zjednávající vztah mezi vzory z minulosti, př́tomností jedince a jeho vizí sebe sama v budoucnosti a zpř́ítomňující utopii globální společnosti míru (Ikeda 1972, s. 179, 78, 84, 115, 142). Spojování lidí s lidmi, věcmi, místy a hodnotami je jednou ze základních funkcí svitku. Webové stránky SGI-ČR uvádějí: „Gohonzon, s vírou praktikujícího a čantováním Nam-mjóhó-renge-kjó, působí jako stimulátor k aktivování životního stavu Buddhovství, (sic!) vrozeného každému člověku“ („Gohonzon“ 2014). Zároveň propojuje prostory geograficky vzdálené, což dokládá například telefonický rozhovor s Ladislavem v roce 2014, při kterém uvedl, že čantují za zlepšení situace na Ukrajině.

2 Starší brožurka obsahuje následující alternativu: „Všechny Gohonzonové pocházejí z Dai Gohonzonu, který Ničiren Daišónin namaloval 12. října 1279 a jinými slovy: všechny Gohonzony jsou přepisem Dai Gohonzonu“ SGI-ČR (2008). Dochází zde k oživení předmětu (Gohonzonové), $\mathrm{s}$ čímž jsem se v rozhovorech se členy a při mítincích také několikrát setkala. 
Gohonzon je předmětem, který, stejně jako daimoku, ustavuje komunitu. Podmínky jeho získání a důležitost připisovaná jeho vlastnění ovšem nejsou jednoznačné a neměnné. Propojování jedince s komunitou skrze Gohonzon má svá lokální specifika, na která upozornila Florencia, ERASMUS studentka pocházející z Jižní Ameriky:

Poprvé jsem se setkala se SGI přes mého dobrého přítele Mária, který je dnes regionálním vedoucím divize mladých mužů. Mário prezentoval na semináři o nevládních organizacích a mírových projektech. Byla jsem velmi zvědavá, jak může nevládní organizace pracující pro mír být zároveň náboženskou organizací. Tato zvědavost mě dovedla k účasti na dvou setkáních, po kterých jsem hned obdržela Gohonzon. V mé komunitě věříme, že když bych se já - dlouhodobý člen - při praktikování necítila př́jemně bez vlastního Gohonzonu, proč by to měl takto dělat nový člen? Věríme, že se všichni učíme prostřednictvím víry a praxe.

Florencia viděla velký rozdíl v přístupu k udílení Gohonzonu v domácí komunitě a v České republice. Dle jejího popisu je členem jedinec již před tím, než obdrží svitek. V imperativu upozorňuje, že by proces neměl trvat dlouho, nebot' praktikování bez Gohonzonu není příjemné. Imperativ je vložen do úst domácí komunitě s odkazem na to, že Gohonzon zvyšuje kvalitu praxe. Miko, manželka vedoucího SGI-ČR, k podmínkám obdržení svitku uvedla:

Aby člověk dostal Gohonzon, musí ho chtít na celý život. Nejen to zkusit. Musí chtít pokračovat celý život a pravidelně dělat gongjó. A chodit na mítinky, protože dostat Gohonzon a praktikovat o samotě dlouho nevydrží [...] Vedoucí s nimi o tom musí mluvit, jestli to opravdu chtějí a budou pokračovat. Musí chodit na mítinky.

Získání svitku Miko prezentovala jako závazek celoživotního praktikování a pravidelného setkávání se SGI. Rozhodnutí je v rukou vedoucího národní komunity, který žádá o Gohonzon pro nového člena v hlavním sídle SGI v Japonsku. Vyprávění Florencie, situace některých členů v předrevolučním Československu, ale také př́klady ze současnosti dokládají, že ne všichni členové Gohonzon vlastní. Př́ípad Patricka a jeho bratra z Afriky ukazuje situaci, kdy je Gohonzon sdílen členy jedné domácnosti. Ptala jsem se Patricka, jak je možné být členem a nemít vlastní svitek:

Patrick: To, že jsi člen, znamená, že máš Gohonzon. Ale můžeš být člen a ještě nemít Gohonzon, protože jsi teprve požádal. Ale když požádáš, tak dostaneš. Když začneš ten buddhismus praktikovat, hned víš, že ten Gohonzon potřebuješ. A když říkám automaticky, myslím tím, že je to normálně jenom proces. Staneš se členem a začneš mít potřebu. Víš, že je to dủležitý, abys měla Gohonzon. Ale můžeš být členem a nemít Gohonzon.

Já: A jak se teda staneš tím členem?

Patrick: Když chceš být buddhistou. Nebo jednodušeji: když chceš být member Sóka Gakkai.

Já: Co to znamená teda?

Patrick: No, být člen, to znamená se k tomu hlásit.

Já: Jak se k tomu hlásit?

Patrick: Musíš najít organizaci. Tady je organizace. Když zadáš do internetu Sóka Gakkai-Česká republika, tak dostaneš webové stránky s kontaktem na Sóka Gakkai. Tak tam pak můžeš zavolat, setkat se, můžeš tam přijít a promluvit si. Říct: „Chtěla bych být členka Sóka Gakkai.“ No, a pak se staneš členkou. Začneš normálně chodit na ty mítinky. Naučíš se, jací mají být členi Sóka Gakkai, a chodíš na ty akce, co pořádají. 
Stát se členem může dle Patricka jedinec na základě dvou aspektů: vlastního rozhodnutí a aktivní účasti na setkáních. Nicméně nabytí členství je dle něj dáno přítomností svitku v domácnosti. Být členem a nemít Gohonzon je situace, která není běžná, a Patrick touto zmínkou legitimizuje své a bratrovo členství při vlastnění jednoho svitku.

Jakkoliv důležitou roli hraje přítomnost svitku v domácnosti, v důsledku sporů o pravost kopií s Ničiren šóšú SGI nejen snížila důležitost způsobu výroby kopií, ale také začala zdůrazňovat pojetí svitku jakožto zrcadla. Toto zrcadlo má odrážet Gohonzon uvnitř člověka. Pozice jedince oproti svitku je klíčová. Kniha Buddha ve tvém zrcadle svým názvem upozorňuje na funkci, kterou svitek plní - odráží čistou přrirozenost člověka v té nejvyšší kvalitě. V podkapitole „Změňte svou karmu“ (Hochswender et al. 2017, s. 44-47) je návod, jak vidět a proměnit stav věcí a vlastní předurčenost:

Když pak odř́káváme Nam-mjóhó-renge-kjó, začneme vrhat světlo na záporné stránky naší karmy - zřetelně vidíme své nedostatky - a tak můžeme učinit kroky k proměně sebe sama a svého osudu. Aby nastínil tento proces nahlížení sebe sama, použil Ničiren metaforu zrcadla. (Hochswender et al. 2017: 46)

Vystavování se svitku je nahlížením Mystického zákona a spolu s recitací má zdokonalit vnitřní Gohonzon. Jedná se o další ikonoklaš, nyní v rámci fungování SGI, kdy ve specifických situacích může docházet k dočasnému nahrazení materiálního svitku za Gohonzon permanentně latentně prrítomný uvnitř člověka. Tělo člověka přesahuje důležitost svitku a je novým obrazem, ke kterému se upíná pozornost humanistického buddhismu SGI. Zamezení přístupu k Dai-Gohonzonu a výrobě kopií i přechodné stavy praktikujících bez svitku ukazují místa, kdy dochází k vyjednáváním týkajících se prvních třech zdrojů sociologických nejistot - povaze skupiny, povaze aktérství a povaze předmětu. Jinými slovy - události, kdy se explicitně řeší způsoby vymezení komunity SGI, kdy je potřeba rekonfigurovat Gohonzon, i situace vyžadující relokalizaci zdrojů moci zviditelňují způsoby, jakými SGI upozad’uje roli svitku jakožto materiálního předmětu. Zmiňované gošó uvádí, že hledat Gohonzon vně sebe sama je omyl („The Real Aspect of the Gohonzon“ n.d.). „Nikdy nehledejte Gohonzon mimo sebe sama. Gohonzon existuje pouze uvnitř smrtelného těla nás obyčejných lidí, kteří přijmou Lotosovou sútru a čantují Nam mjóhó renge kjó.“ Zkoumání předmětu a rozporných vyjádření týkajících se jeho povahy jsou jedním z klíčových zájmů ANT. Různá pojetí Gohonzonu, a to jak v synchronní, tak asynchronní perspektivě, vyústily v přemístění tohoto ústředního prvku do lidského těla nové inkarnaci. Po rozchodu s Ničiren šóšú SGI dominuje představa „Gohonzonu v každém člověku“ a přesvědčení, že „máme důvěřovat Gohonzonu v sobě“ (Yorida n.d. b).

\section{Závěr: myslet SGI skrze Gohonzon}

Mikrovhled do SGI získaný díky pohybu mezi praktikujícími mi umožnil poznávat jejich pojetí světa a heuristiku, s jakou přistupují $\mathrm{k}$ řešení problémů pomocí rituálu čantování daimoku před Gohonzonem. Ačkoliv klíčový problém ve vědeckém výzkumu náboženství tvoří vztah mezi materiálním a nemateriálním, zvolená východiska mi umožnila zkoumat rituál se zaměřením na způsoby materializace klíčových aspektů praxe. A priori jsem 
odmítla uvalovat „falešnou asymetrii mezi lidské záměrné jednání a materiální svět kauzálních vztahư" (Latour 2005: 76) a přijala jsem předpoklad, že figurace prvků konstituujících nábožensky motivované jednání člověka a věcí nejsou a priori nikterak ohraničeny a nejsou stabilní.

Následování cest Gohonzonu přineslo odpovědi na otázky týkající se povahy skupiny, povahy jednání, povahy objektů a povahy faktů (Latour 2005, s. 21-121). Ukázala jsem Gohonzon jakožto důležitou součást světatvorných procesů v SGI, mezi jehož funkce spadá zprostředkovávání Mystického zákona, zrcadlení vnitřního stavu člověka či propojení členů komunity. Sledovala jsem nejen jednání lidských aktérů, ale též situace, kdy Gohonzon vystupoval jako aktér ovlivňující jednání členů i jako zprostředkovatel spojení s jinými místy a časy. Ukázala jsem také způsoby zpřítomňování Gohonzonu v těle člověka. Demonstrovala jsem situace, ve kterých došlo k rekonfiguraci aktér-sítí ustavujících hmotnou existenci fráze a svitku, situace, ve kterých je jedna aktér-sít' upozad’ována na úkor druhé. Situace, kdy se do popředí dostává člověk jakožto ztělesnění daimoku, zároveň ukazují aktéra-člověka a lidské tělo jako složitý shluk nestabilních a svou povahou různorodých prvků (srov. Law 1994, s. 24). Ukázala jsem svitek ne jako artefakt ve smyslu statického hmotného objektu, ale jako výsledek vyjednávání aktérů, jejichž způsoby kooperace se proměňují, přičemž hranice a lokalizace svitku není samozřejmá. Využití konceptu ikonoklaše umožnilo vidět, jakým způsobem dochází ke střetávání podob, jež Gohonzon v průběhu historie získal, a popsat situace, $v$ nichž jednotliví jedinci, instituce, texty i svitky samy tyto nové podoby definovali. Z výzkumu je zřejmé, že Gohonzon v lidském těle získal u SGI na důležitosti oproti Gohonzonu jakožto svitku. Toto sepětí Buddhova světa a lidského těla je možné chápat jako projev náboženského antropocentrismu či buddhistického humanismu, na kterém se ukazuje, že náboženství skutečně nefunguje jako autonomní separátní oblast - lidští aktéri využívají předměty, aby ovlivňovaly realitu, předměty nejsou statickou veličinou a mnohdy zásadním způsobem ovlivňují jednání lidí. Rozmotávání zlatého klubíčka započaté ve vídeňské SGI zůstává nicméně nedokončeným procesem započatým Gohonzonem, jako prodlouženi toku Gohonzonů.

Tento text nabízí vhled do světa Ničirenových buddhistů způsobem doposud nezprostředkovaným, tedy prostřednictvím praxe čantování před uctívaným svitkem. Ačkoliv je empirická studie $\mathrm{z}$ velké části zakotvená $\mathrm{v}$ České republice, $\mathrm{v}$ mnoha aspektech také na rozdíl od ostatních národně orientovaných studií překračuje její hranice. ANT umožnil překonávat nejen hranice národa a státu, dovolila zkoumat působení SGI prostřednictvím proměn ústředního rituálního předmětu, čímž se zviditelnila rozmělněnost a propustnost oblasti, která je sociology označována jako náboženská. Materializování daimoku, at' už do formy prvotního svitku, jedné kopie či těla čantujícího, je procesem, kdy se Mystický zákon realizuje v tomto světě - dochází k nastolování rádu.

Studie demonstruje, že zkoumání náboženské reality prostřednictvím materiální věci s pomocí ANT se zaměřuje na běžnou praxi žitého náboženství namísto abstraktního teoretizování o doktrínách a dogmatech víry. Není návratem $\mathrm{k}$ fenomenologii náboženství, nesnaží se vejít do předmětu a vcítit se do něj. Jak ukazuji, je př́mým opakem hledání povahy a podstaty předmětu mimo časoprostorový rámec. Namísto psychologizace výzkumné praxe přichází klasické etnografické postupy, zájem o heuristiku zkoumaných a také snaha o zapojení 
dalších možných nástrojů k porozumění realitě. Při takto orientovaných výzkumech vzniká prostor překračovat výzkumné hranice vlastních specializací v oboru i např́íc disciplínami, zkoumat sociální realitu $\mathrm{v}$ její sémiotické, materiální i nemateriální poloze. Sociologové náboženství mají možnost studovat náboženství jako jakékoliv jiné praktiky a zároveň přijmout výzvu k rozšiřování vlastní specializace a interdisciplinární spolupráci.

\section{Literatura}

„Activities for Peace.“ SGI, n.d. Cit. 30. záŕí 2015 (http://www.sgi.org/about-us/activities-for-peace. html).

BARONE, Carlo. 2007. „A Neo-Durkheimian Analysis of a New Religious Movement.“ Theory and Society 36(2): 117-140.

BELL, Jeffrey. 2010. „Latour on Factishes and Belief.“ Cit. 21. září 2017 (https://schizosoph.wordpress. com/2010/07/20/latour-on-factishes-and-belief/).

CHILSON, Clark. 2014. „Cultivating Charisma: Ikeda Daisaku's Self Presentations and Transformational Leadership.“ Journal of Global Buddhism 15: 65-78.

ClARKE. Peter B. (ed.). 2000. Japanese New Religions in Global Perspective. Richmond: Curzon.

CLARKE, Peter B. a Jeffrey SOMERS (eds.). 1944. Japanese New Religions in the West. London: Routledge.

„Co je Sóka Gakkai?“ SGI-CR, 2014. Cit. 30. září 2015 (http://www.sokagakkai.cz/soka_gakkai/co_je_ soka_gakkai.html).

„Daisaku Ikeda. SGI President.“ SGI, n.d. Cit. 30. září 2015 (http://www.sgi-usa.org/newsand events/ newsroom/mediakit/ikedaprofile.php).

DOBELLAERE, Karl. 2001. Soka Gakkai: From Lay Movement to Religion. Salt Lake City: Signature Books.

ESPIRITO SANTO, Diana a Nico TASSI (eds.). 2013. Making Spirit: Materiality and Transcendence in Contemporary Religions. New York: I.B. Tauris.

„FAQ.“ Soka spirit, n.d. Cit 21. března 2018 (http://www.sokaspirit.com/original/nichikan-gohonzon/ faq.html).

FENN, Richard. K. 2001. „Editorial Commentary: Religion and the Secular; The Sacred and the Profane: The Scope of the Argument." Pp. 3-22 in Richard K. FENN (ed.). The Blackwell Companion to Sociology of Religion. Oxford: Blackwell Publishing.

FUJDA, Milan. 2013. „Proč nestudovat náboženství: K sociologickému uspořádávání skutečnosti.“ Sociální studia 10(3): 13-43.

FUJDA, Milan. 2015. „What Would an Informant Tell Me after Reading My Paper? On the Theoretical Significance of Ethical Commitment and Political Transparency in Symmetrical Practice Studying Religion(s).“" Religio: revue pro religionistiku 23(1): 57-86.

FUJDA, Milan. 2016. „From Religion to Ordering Uncertainity: A Lesson from Dancers.“ Pp. 189-206 in Ingman PEIK, Utriainen TERHI, Hovi, TUIJA a Broo MANS (eds.). The Relational Dynamics of Enchantment and Sacralization: Changing the Terms of the Religion Versus Secularity Debate, Sheffield: The Study of Religion in a Global Context.

„Gohonzon.“ SGI-CR, 2014. Cit. 30. září 2015 (http://www.sokagakkai.cz/praktikovani_buddhismu/ gohonzon.html).

HAMMOND, Philip E. a David W. MACHACEK. 2004. Soka Gakkai in America. Oxford: University Oxford Press. 
HARMAN, Graham. 2016. Immaterialism: Objects and Social Theory. Cambridge: Polity Press.

HOCHSWENDER Woody, Greg Martin a Ted MORINO. 2017. Buddha ve tvém zrcadle: Praktický buddhismus a hledáni sebe sama. Praha: Soka Gakkai International - Česká republika z.s.

IKEDA, Daisaku. 1972. The Human Revolution. Volume 1. New York: Weatherhill.

KISALA, Robert. 2004. „Soka Gakkai: Searching for the Mainstream.“Pp. 139-152 in James R. LEWIS a Jasper A. PETERSEN (eds.). Controversial New Religions. Oxford: Oxford University Press.

KOBES, Tomáš. 2018. Panenko Skákavá! Módy existence paměti. Mervart.

KONOPÁSEK, Zdeněk. 2010. „V čem spočívá pravda náboženské skutečnosti? Sociologický pohled na mariánská zjevení a démonické posedlosti.“ Biograf 52-53: 89-101.

KONOPÁSEK, Zdeněk a Jan PALEČEK. 2006. „V moci d’ábla: Exorcismus věřícnýma očima.“ Biograf 40-41: 138-171.

KONOPÁSEK, Zdeněk a Jan PALEČEK. 2011. „The Principle of Symmetry from the Respondents' Perspective: Possessions, Apparitions and Mental Illnesses in Research Interviews with Clerics.“ Forum Qualitative Sozialforschung / Forum: Qualitative Social Research 12 (1). Cit. 20. brezna 2019 (http://www.qualitative-research.net/index.php/fqs/article/view/1592/3101).

KONOPÁSEK, Zdeněk a Jan PALEČEK. 2012. „Apparitions and Possessions as Boundary Objects: An Exploration into Some Tensions between Mental Health Care and Pastoral Care." Journal of Religion and Health 51(3): 970-985.

KVÍČALOVÁ, Anna. 2019. Listening and Knowledge in Reformation Europe: Hearing, Speaking and Remembering in Calvin's Geneva. Cham: Palgrave Macmillan.

LATOUR, Bruno. 1993. We Have Never Been Modern. Cambridge: Harvard University Press.

LATOUR, Bruno. 2001. „What is Iconoclash? Or Is There a World beyond the Image Wars?“ Pp. 14-37 in Bruno LATOUR a Peter WEIBEL (eds.). Iconoclash, beyond the Image Wars in Science, Religion and Srt. Cambridge, MA: MIT Press.

LATOUR, Bruno. 2004. „How to Talk about the Body? The Normative Dimension of Science Studies.“ Body and Society 10(2/3): 205-229.

LATOUR, Bruno. 2005. Reassembling the Social: An Introduction to Actor-Network-Theory. Oxford: Oxford University Press.

LATOUR, Bruno. 2010. On the Modern Cult of Factish Gods. Durham: Duke University Press.

LATOUR, Bruno. 2016. Stopovat a skládat světy s Bruno Latourem: výbor z díla 1998-2013. Praha: Tranzit.cz.

LAW, John. 1994. Organising Modernity: Social Order and Social Theory. Oxford: Blackwell.

„Lidská revoluce.“ SGI-CR, 2014. Cit. 30. září 2020 (http://www.sokagakkai.cz/studijni_materialy/ lidska_revoluce.html).

„Lotosová sútra.“ SGI-CR, 2014. Cit. 30. září 2020 (http://www.sokagakkai.cz/buddhismus_nicirena_daisonina/lotosova_sutra.html).

MACHACEK, David a Bryan WILSON (eds.). 2000. Global Citizens: The Soka Gakkai Buddhist Movement in the World. Oxford: Oxford University Press.

METRAUX, Daniel A. 2001. The International Expansion of a Modern Buddhist Movement: The Soka Gakkai in Southeast Asia and Australia. Maryland: University Press of America.

METRAUX, Daniel A. 1994. The Soka Gakkai revolution. New York: University Press of America.

„Nam-Mjóhó-Renge-Kjó.“ SGI-CR, 2014. Cit. 30. záŕí 2020 (http://www.sokagakkai.cz/praktikovani_buddhismu/nam_mjoho_renge_kjo.html).

PALEČEK, Jan. 2010. „Mariánský zázrak ve světle sociologie, sociologie ve světle slunečního zázraku.“ Biograf 52-53: 41-66.

„People \& Perspectives.“ SGI, n.d. Cit. 16. května 2018 (https://www.sgi.org/people-and-perspectives/). rocham2010. „What is the Gohonzon.“ SGI-USA, 2014 Cit. 16. května 2020 (https://buddhismsgiusa. wordpress.com/2014/09/21/what-is-the-gohonzon/). 
SEAGER, Richard H. 2006. Encountering the Dharma. Daisaku Ikeda, Soka Gakkai, and the Globalization of Buddhist Humanism. Berkeley: University of California Press.

SEGAL, Robert A. 1983. „In Defense of Reductionism.“ Journal of the American Academy of Religion 51(1): 97-124.

SEGAL, Robert A. 1985. „Anthropological Definitions of Religion.“Zygon 20(1): 78-79.

SGI Deutschland. 2001. Eine Philosophie des Lebens: Einführung in den Buddhismus Nichirens. Město a nakladatel není uveden.

SGI-ČR. (2008). Buddhismus Ničirena Daišónina: Filozofie vítězného života. Praha: SGI-ČR.

SGI-ČR. (n.d. a) Základy Budhismu Ničirena Daišónina. Město a nakladatel není uveden.

SGI-ČR. (n.d. b). Sbirka s př́běhy. Město a nakladatel není uveden.

SGI-ČR. (n.d. c). Text modlitby buddhismu Ničirena Daišónina. Není uvedeno. Město a nakladatel není uveden.

SNOW, David A. 1993. Shakubuku: A Study of the Nichiren Shoshu Buddhist Movement in America 1960-1975. New York: Garland.

SPALOVÁ, Barbora. 2012. Bůh ví proč: Studie pamětí a režimů moci v křest’anských církvích v severních Čechách. Brno: Centrum pro stadium demokracie a kultury.

„Stories and Reflections on the Buddhist Approach to Life.“ (n.d.). Cit. 30. 9. 2015 (https://www.sgi.org/ people-and-perspectives/).

„The Gohonzon - Observing the Mind.“ SGI, n.d. Cit. 30. záŕí 2015 (http://www.sgi.org/about-us/buddhism-in-daily-life/the-gohonzon-observing-the-mind.html).

„The Gohonzon.“ SGI, n.d. Cit. 30. záŕí 2015 (http://www.sgi.org/about-us/gohonzon.html).

„The Gohonzon: Diagram of the Gohonzon.“ SGI-USA, 2017. Cit. 31. března 2018 (http://www.sgi-usa. org/memberresources/beginnersresources/diagramofgohonzon.php).

„The Real Aspect of the Gohonzon.“ Nichiren library, n.d. Cit. 21. března 2017 (http://www.nichirenlibrary.org/en/wnd-1/Content/101).

THOMAS, William I. a Florian ZNANIECKI. 1918. The Polish Peasant in Europe and America. Vol I. New York: Dover.

„Warning to SGI.“ Anonymous, n.d. 30. záŕí 2015 (https://www.youtube.com /wat ch?v=AHg5MFPK$3 \mathrm{Cg})$.

WEBER, Max. 1998. „Věda jako povolání.“ Pp. 109-134 in Max WEBER. Metodologie, sociologie, politika. Praha: OIKOYMENH.

WILSON, Bryan a James CRESSWELL (eds.). 1999. New Religious Movements: Challenge and Response. London: Routledge.

„Základní praktikování.“ SGI-CR, 2014. Cit. 30. září 2020 (http://www.sokagakkai.cz/praktikovani_ buddhismu/zakladni_praktikovani.html).

„Zkušenosti.“ SGI-CR, 2014. Cit. 30. září 2020 (http://www.sokagakkai.cz/praktikovani_buddhismu/ zkusenosti.html).

\section{Autorka}

Petra Tlčimuková je religionistka a socioložka. Věnuje se studiu přenosu a proměn náboženství, zejména šíření buddhismu, teorii a metodologii sociálních věd. Působí jako odborná asistentka na Katedře sociologie Univerzity Hradec Králové a přednáší také na Teologické fakultě Jihočeské univerzity.

Kontakt: Petra.tlcimukova@uhk.cz 